\title{
Chairs letter
}

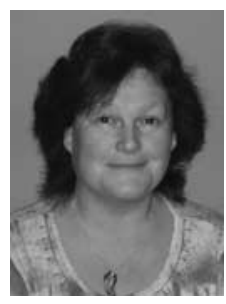

Manda Dunne (SRN ONC ENB182)

BARNA Chair

Dear Members,

$\mathrm{I}$ is with great pleasure that I have had the opportunity to become your Chair again for the near future, a role that I feel very honoured to fulfil. As some of you know, because you were there, BARNA (British Anaesthetic and Recovery Nurses Association) was part of the ICPAN (International Conference for Perianaesthesia Nurses) conference in October 2011 in Toronto, Canada. It was a phenomenal success, which resulted in us closing registration because we could not physically fit in any more people! This had been 2 years in the making and planning and was worth every moment of it. We had speakers from many parts of the globe and delegates to match. It was a very proud time for us all.

Changes and new experiences are always exciting, challenging and sometimes frightening. BARNA is about to embark on some major changes that we hope will build a bright and secure future for us all. One change, and a definite break from tradition, is that we will be holding our annual conference in November this year, and it will be in London. The final plans will be made available very soon, so please look out for the news of this event.

We are very mindful that our attention has been very much International in recent months but we are concentrating on building on our association to deliver much more to our members. Among other things, we are exploring projects like educational packages as part of an online initiative, which we hope will provide our members with education at the touch of a button.

I am very passionate about anaesthetic and recovery nursing as I know I have said before, and I would implore you to please bear with us through this change. We are working very hard to deliver an association that we see as exciting, educational and innovative, and most of all, one that we are proud of. The world is a changing place and after 25 years of loyal support from our members we are still here and striving to support you in your daily work and to provide clinical excellence that we believe in so strongly.

Thank you. 